urer); Prof. Kirtley F. Mather, professor of geology, Harvard University; and Frank R. Ford, editor, Evansville Press, Evansville, Ind. Other trustees are: Dr. Edwin G. Conklin, Princeton University; Dr. Rene J. Dubos, Rockefeller Institute for Medical Research, New York City; A. H. Kirchhofer, managing editor, Buffalo Evening News, Buffalo, N.Y. ; Dr. Karl Lark-Horovitz, Purdue University ; Dr. L. A. Maynard, Comell University; Charles E. Scripps, Cincinnati, Ohio; Dr. Harlow Shapley, director, Harvard College Observatory (president); Harry L. Smithton, of La Jolla, Calif.; Neil H. Swanson, executive editor, Sun Papers, Baltimore, Md.; and Dr. Alexander Wetmore, secretary, Smithsonian Institution (vice-president and chairman of the executive committee). Science Service is an endowed, non-profit-making institution for the popularization of science. The board of trustees consists of fifteen representatives, three each being nominated by the American Association for the Advancement of Science, the National Academy of Sciences, the National Research Council, the E. W. Scripps Estate and by the journalistic profession. Mr. Watson Davis is still the secretary of Science Service, the address of which is 1719 N Street N.W., Washington 6, D.C.

\section{Paris Office of the Southwest Research Institute,} Texas

THE Southwest Research Institute, San Antonio, Texas, has established at 207 Rue de l'Université, Paris, an office to facilitate the handling of work for European companies and individuals similar to the three already operating in San Antonio, Houston (Texas) and New York for the North American continent. In addition to representing the Southwest Research Institute, which conducts industrial and agricultural research for companies, associations and individuals on a cost-fee basis, the Paris office also handles European matters for the Institute of Inventive Research, which serves manufacturers and inventors, and for the Foundation of Applied Research, which conducts fundamental scientific investigations in agriculture and medicine, all three being nonprofit institutions founded by Mr. Tom Slick, a Texas oil producer and rancher. The director of the Paris office is M. Servan G. Cantacuzene, who is a graduate of the Universities of Bucharest and Paris, and is a former research and consulting engineer for French and Rumanian oil companies.

Royal Society of South Africa: Officers for 1950

THE following have been elected to the Council for 1950 of the Royal Society of South Africa : President, Prof. R. W. James; Honorary General Secretary, A. J. H. Goodwin; Honorary Treasurer, J. G. Rose; Honorary Editor of Transactions, Dr. F.. Walker; Honorary Librarian, Dr. E. Newbery ; Other Memibers of Council, Dr. W. F. Barker, E. Batson, Dr. J. Jackson, Dr. W. Pugh, D. L. Scholtz, Dr. J. L. B. Smith, W. J. Talbot, Dr. C. J. v.d. Horst and Dr. C. L. Wicht.

\section{Physical Society :}

Officers for |950-5|

$\mathrm{AT}_{\mathrm{T}}$ the annual general meeting of the Physical Society, held at the Science Museum on May 9, the reports of the Council and Treasurer and the accounts and balance sheet for 1949 were presented and adopted, and the officers and Council for 1950-51 were elected as follows: President, Prof. L. F. Bates;
Vice-Presidents uho have filled the office of President, Prof. C. H. Lees, Sir Erank Smith, Sir Owen Richardson, Dr. W. H. Eccles, Prof. A. O. Rankine, Mr. T. Smith, Dr. Allan Ferguson, Sir Charles Darwin, Prof. E. N. da C. Andrade, Sir David Brunt, Prof. G. I. Finch, Prof. S. Chapman; Vice-Presidents, Dr. W. Jevons, Mr. C. H. Collie, Prof. R. Peierls, Dr. D. Roaf ; Honorary Secretaries, Mr. C. G. Wynne, Dr. H. H. Hopkins; Honorary Foreign Secretary, Prof. E. N. da C. Andrade ; Honorary Librarian, Dr. R. W. B. Pearse; Ordinary Members of Council, Dr. A. C. G. Menzies, Mr. J. H. Awbery, Dr. R. C. Evans, Prof. L. C. Martin, Dr. C. E. Wynne-Williams, Dr. A. G. Quarrell, Dr. A. B. Wood, Prof. Willis Jackson, Prof. H. S. W. Massey, Mr. L. J. Davies, Prof. W. V. Mayneord, Dr. R. W. B. Stephens. Owing to the recent sudden death of Dr. H. Shaw, honorary treasurer of the Society, this office has not yet been filled.

Summer Meeting

The Summer Meeting of the Physical Society will be held this year at the University of Liverpool on July 7 and 8, from 10.00 a.m. to 5.00 p.m. The subjects of the meeting will be nuclear physics and the theory of solids (including dielectrics). Members of the Experimental and Theoretical Physics Depart. ments of the University will speak on the theory of solids (including dielectrics) on Friday morning, July 7 ; and on nuclear physics (mainly theoretical) on Friday afternoon. Saturday morning, July 8, will be mainly devoted to experimental work. On Saturday afternoon there will be a visit to the Nuclear Physics Laboratory, including the $400-\mathrm{MeV}$. synchroeyclotron now under construction. The Conference will be open to non-members on payment of a fee of 10s. Inquiries for application forms should be addressed to the offices of the Physical Society, 1 Lowther Gardens, Prince Consort Road, London, S.W.7, and applications for attendance should be received at Liverpool not later than May 31.

\section{Polydactyly in Mice}

Prof. R. A. FIsher writes: "Will you please correct the statement in my letter published on March 11, p. 407, to the effect that the newly isolated gene for polydactyly is linked with leaden, $l n$. It appears, more probably, to be linked with dilute, $d$, in the second chromosome, the recombination fraction being approximately 30 per cent"

\section{Announcements}

Mr. H. P. Moon, at present lecturer in charge of the Department of Zoology, has been appointed professor of zoology in the University College, Leicester. The following appointments in the College have also been made: Dr. J. R. S. Fincham to be lecturer in genetics, and Dr. C. Eaborn to be lecturer in chemistry.

The Chemical Research Laboratory, Department of Scientific and Industrial Research, at Teddington, Middlesex, is again holding a series of 'open days' this year. There will be four sessions, on June 28 (afternoon), June 29 (afternoon), and June 30 (morning and afternoon). The afternoon of June 28 has been set aside for representatives of industrial firms who have not previously received invitations, and the director would be glad to receive applications from firms up to June 19. It is not necessary for those invited in previous years to apply again. 